Finanse, Rynki Finansowe, Ubezpieczenia nr 3/2017 (87), cz. 1

\title{
Audyt wewnętrzny w doskonaleniu budżetowania zadaniowego oraz kontroli zarządczej w jednostce samorządu terytorialnego
}

\author{
Olga Szolno*
}

\begin{abstract}
Streszczenie: $\mathrm{Cel}$ - Zaprezentowanie roli audytu wewnętrznego w prawidłowym funkcjonowaniu budżetowania zadaniowego i kontroli zarządczej.

Metodologia badania - Analiza literatury przedmiotu, aktów prawnych, materiałów źródłowych, zastosowano także metodę obserwacji oraz przeprowadzono indywidualne wywiady pogłębione z pracownikami badanych jednostek (dyrektorem wydziału budżetu oraz 4 osobami zatrudnionymi w tym wydziale).

Wynik - Określono rolę działań audytowych w funkcjonowaniu budżetowania zadaniowego i kontroli zarządczej, opisano również wzajemne zależności, jakie zachodzą między nimi.

Oryginalność/wartość - Osiąganie celów i realizowanie zadań przez jednostki samorządu terytorialnego wymaga wykorzystania różnych instrumentów w procesie decyzyjnym, w związku z tym kierownictwo jednostki samorządu terytorialnego powinno mieć świadomość, że właściwie należy powiązać ze sobą budżetowanie zadaniowe, kontrolę zarządczą i audyt wewnętrzny, aby zmaksymalizować płynące z nich korzyści.
\end{abstract}

Słowa kluczowe: audyt wewnętrzny, kontrola zarządcza, budżet zadaniowy

\section{Wprowadzenie}

Efektywne realizowanie procesów gromadzenia oraz rozdysponowania środków publicznych jest wyzwaniem dla jednostek sektora publicznego. Chcąc efektywnie gospodarować, muszą wprowadzać narzędzia ułatwiające osiąganie zamierzonych celów. Ponadto ich działalności powinny nierozłącznie towarzyszyć kontrola i nadzór - elementy procesu dbania o racjonalność.

Zgodnie z zasadami nowego zarządzania publicznego, jednostki samorządu terytorialnego powinny wykorzystać metody oraz techniki zarządzania, które stosowane są w sektorze prywatnym. Ustawa o finansach publicznych wprowadziła dlatego kontrolę zarządczą, budżetowanie zadaniowe i audyt wewnętrzny jako instrumenty pozwalające na dokonanie pożądanych zmian w sposobie wydatkowania środków. Korzyścią z ich implementacji może być wzrost skuteczności i efektywności podejmowanych działań.

Głównym celem artykułu jest przedstawienie roli audytu wewnętrznego w funkcjonowaniu budżetowania zadaniowego oraz kontroli zarządczej. Aby osiągnąć założony cel,

\footnotetext{
* mgr Olga Szołno, Uniwersytet Marii Curie-Skłodowskiej w Lublinie, Wydział Ekonomiczny, Zakład Rachunkowości, e-mail: olga.szolno@poczta.umcs.lublin.pl.
} 
dokonano przeglądu literatury, materiałów źródłowych oraz wykorzystano przeprowadzone przez autorkę badania, takie jak obserwacja oraz indywidualne wywiady pogłębione z pracownikami wybranych jednostek samorządu terytorialnego (urzędów miast na prawach powiatu).

\section{Budżetowanie zadaniowe i kontrola zarządeza jako instrumenty zwiększające efektywność i skuteczność funkcjonowania jednostek samorządu terytorialnego}

W ustawie o finansach publicznych wielokrotnie wskazano na znaczenie zasad efektywności i skuteczności, narzucając obowiązek ich stosowania. Należy więc wydatkować środki publiczne ,z zachowaniem zasad uzyskiwania najlepszych efektów z danych nakładów oraz optymalnego doboru metod i środków służących osiągnięciu założonych celów” (Ustawa z 27 sierpnia 2009 r.; t.j. Dz.U. 2016, poz. 1870 z późn. zm.). Istotność omawianych zasad wzmocniono wprowadzeniem obowiązku wdrożenia kontroli zarządczej oraz narzucenia jednostkom rządowym planowania wydatków w układzie zadaniowym (co jest fakultatywne dla jednostek samorządowych). Audyt wewnętrzny wspierają kierownictwo jednostki w realizacji celów i zadań przez systematyczną ocenę, zwłaszcza pod kątem skuteczności i efektywności działań, w tym realizacji budżetu w układzie zadaniowym (Zawadzka-Pąk, 2013).

Budżetowanie zadaniowe stanowi narzędzie zarządzania wydatkami publicznymi za pomocą wyznaczonych celów (skonkretyzowanych i zhierarchizowanych), co ułatwia osiągnięcie rezultatów mierzonych odpowiednimi miernikami (Lubińska, Strąk, Lozano-Platonoff, Będzieszak, Głodek, 2007). Kontrola zarządcza stanowi z kolei ogół działań, które są podejmowane dla zapewnienia realizacji celów i zadań w sposób efektywny, racjonalny, terminowy oraz zgodny z obowiązującym prawem i wyznaczonymi standardami. Jednym z jej głównych celów jest zapewnienie „skuteczności i efektywności działania” oraz „efektywności i skuteczności przepływu informacji” (Ustawa z 27 sierpnia 2009 r.; t.j. Dz.U. 2016, poz. 1870 z późn. zm.).

Sformułowanie celów, zadań oraz dobór mierników to wspólne elementy kontroli zarządczej oraz budżetowania zadaniowego. Dokonując porównania obu systemów, należy wskazać, że w ramach budżetu zadaniowego wyznaczone mierniki powiązane są z poziomem środków budżetowych. W kontroli zarządczej aspekt planistyczny z wyznaczonymi celami do realizacji stanowi podstawę prawidłowej oceny działalności jednostek samorządowych. Jednocześnie obszar ich analizy obejmuje wszystkie istotne elementy wpływające na rezultaty funkcjonowania jednostki. Nie mniej ważny jest aspekt systematyczności obserwacji procesów zachodzących w jednostkach samorządu terytorialnego, pozwalający na bieżącą korektę wszelkich odchyleń w celu zmniejszenia ryzyka związanego z zagrożeniem braku pełnego wykonania celów i zadań budżetowych. Systematyczne monitorowanie staje się podstawą tworzenia aktualnych informacji wykorzystywanych do podejmowania 
decyzji. Tak więc kontrola zarządcza i budżetowanie zadaniowe wykorzystują różnego typu informacje do samoregulacji systemu zarządzania stojącego na straży efektywnej i skutecznej realizacji uchwalonego budżetu. Pomiędzy kontrolą zarządczą a budżetem zadaniowym występuje ścisła zależność. Za pomocą budżetu zadaniowego jednostka zarządza środkami publicznymi poprzez określone cele, a efektywność i skuteczność tego zarządzania mierzona jest $w$ ramach kontroli zarządczej.

Warto nadmienić, że należy odpowiednio zdefiniować, uwzględniając wytyczne konstrukcyjne, cele i zadania (np. precyzyjnie, jasno, zrozumiale dla szerokiego grona odbiorców) oraz mierniki tak, by za ich pomocą możliwa była ocena realizacji wykonywanych zadań (odpowiednie zdefiniowanie mierników jest de facto realizacją zasady przejrzystości i racjonalności wydatkowania zasobów publicznych) (Lubińska, 2009).

\section{Rola audytu wewnętrznego w prawidłowym funkcjonowaniu budżetu zadaniowego i kontroli zarządczej}

Istotne znaczenie dla efektywnego funkcjonowania budżetowania zadaniowego i kontroli zarządczej ma audyt wewnętrzny. Rola audytu znacząco wzrosła po wprowadzeniu do ustawodawstwa powyższych elementów. Pierwotnie odnosił się on jedynie do operacji finansowych odzwierciedlających gospodarowanie środkami publicznymi, z czasem objęto nim całokształt działalności jednostek. Obecnie audyt wewnętrzny jest niezależną, obiektywną działalnością o charakterze zapewniającym i doradczym, która prowadzona jest w celu wniesienia do jednostki wartości dodanej i usprawnienia jej funkcjonowania (Definicja audytu..., 2016). Można zatem stwierdzić, że audyt wspiera organizację w osiąganiu wytyczonych celów i zadań przez systematyczną i konsekwentną poprawę efektywności i skuteczności zarządzania (Czerwiński, 2003; Welcome..., 2006). Audyt musi więc zapewnić systematyczną ocenę funkcjonowania kontroli zarządczej, która stała się jego obszarem kluczowym, wspiera jednostkę w utrzymaniu skutecznych i efektywnych mechanizmów kontroli zarządczej, a także w ich stałym doskonaleniu. Rodzajem audytu wewnętrznego, służącym ocenie sprawności działania procesu planowania i wydatkowania środków publicznych, jest audyt efektywnościowy, którego zadaniem jest „systematyczna analiza oceniająca gospodarność, wydajność i skuteczność” (Opracowanie..., 2008).

Budżet zadaniowy, z mocy prawa, podlega kontroli zarządczej (Ustawa z 27 sierpnia 2009 r.; t.j. Dz.U. 2016, poz. 1870 z późn. zm.), jest wyzwaniem nie tylko dla jednostek implementujących, ale również osób oceniających jego funkcjonowanie, czyli audytorów wewnętrznych. Wdrożenie budżetu zadaniowego wymaga w ramach działalności audytowej określenia odpowiednich metod i technik badania. Konieczne jest zdefiniowanie kryteriów oceny procesu planowania i wydatkowania środków publicznych pod względem ich racjonalności oraz określenia czynników wpływających na efektywność i skuteczność tych procesów (Skoczylas-Tworek, 2013). Szczególnie ważne jest określenie zadań priorytetowych, ponieważ pozwala skierować działania audytu na kluczowe obszary. Wspieranie jednostek 
w osiąganiu założonych celów przyniesie efekty pod warunkiem, że cele są zdefiniowane precyzyjnie oraz właściwie udokumentowane. $\mathrm{W}$ innym przypadku rola audytu ogranicza się do sprawdzenia zgodności podejmowanych działań z literą prawa, co ma drugorzędne znaczenie w procesie decyzyjnym (Dylewski, Filipiak, Gorzałczyńska-Koczkodaj, 2010). Szeroki zakres kontroli wiąże się z koniecznością myślenia w kategoriach efektywnościowych, zaczęto zwracać większą uwagę na rozbieżności między planem a wykonaniem oraz analizę samych wydatków, szczególnie kosztownych zadań.

Należy stwierdzić, że audyt z jednej strony może wspomagać prawidłową implementację budżetu zadaniowego czy też kontroli zarządczej, z drugiej zaś jest „instrumentem” monitorowania okresowego (ewaluacji), ma za zadanie ocenę systemu z punktu widzenia tworzenia szans służących osiągnięciu zakładanych celów. Ewaluacja natomiast obejmuje szeroką, całościową ocenę skuteczności i efektywności podejmowanych działań, likwidację nieefektywnych czynności, wprowadzanie korekt w inicjatywach strategicznych oraz wskazuje potrzebę podejmowania nowych inicjatyw (Skrzypek, 2011).

W pierwszej kolejności ocena audytu obejmować powinna poznanie systemu kontroli zarządczej, budżetowania zdaniowego, ich koncepcji oraz sposobów wdrożenia. Należy przebadać wszystkie elementy konstrukcyjne budżetu zadaniowego oraz kontroli zarządczej, takie jak cele, zadania, mierniki. Dokumentacja opisywanych koncepcji musi zawierać wymogi dotyczące ich konstrukcji, a zadaniem audytu powinno być sprawdzenie zgodności zdefiniowanych elementów z przepisami wewnętrznymi jednostki w tym zakresie. Ponadto należy dokonać oceny poprawności sformułowanych elementów z wytycznymi, ocenić adekwatność ich wyboru oraz całej koncepcji, a także ustalić szansę wykonalności założeń. Na tej podstawie szacuje się ryzyko wystąpienia nieprawidłowości. Jest niezwykle ważne, aby ocenić każdy element $\mathrm{z}$ uwagi na to, że słabość jednego może podważyć zasadność przyjęcia całej koncepcji (Kiziukiewicz, Sawicki, 2013). Powyższa ocena powinna być przeprowadzona na etapie implementacji zarówno budżetu zadaniowego, jak i kontroli zarządczej. Oceniając w ten sposób dobór wszystkich elementów zwiększa się szansa na to, że te dwa instrumenty przyniosą zamierzone korzyści w postaci skutecznego i efektywnego funkcjonowania jednostek, a więc także wydatkowania środków publicznych.

Wyniki audytu będą stanowić zalecenia dla kierownictwa jednostki, wskazując na obszary problemowe i ryzyko nieosiągnięcia założonych korzyści. W takiej sytuacji badana jednostka powinna zweryfikować poprawność doboru elementów i rozważyć ich zmianę. Należy jednak zaznaczyć, że dokonywane to powinno być nie tylko przez samego kierownika, ale w konsultacji z kierownictwem poszczególnych jednostek organizacyjnych oraz z pracownikami merytorycznymi. Niezbędny jest więc sprawny przepływ informacji. 


\section{Funkcja doradcza audytu wewnętrznego w zakresie poprawy efektywności, skuteczności i adekwatności budżetowania zadaniowego i kontroli zarządczej}

Właściwa ocena przyjętych koncepcji budżetowania zadaniowego i kontroli zarządczej uwarunkowana jest znajomością wielu zagadnień. Należy znać istotę i zakres kontroli zarządczej (w tym jej standardy) (Komunikat z 16 grudnia 2009 r.) oraz budżetowania zadaniowego, wszystkie obszary działalności jednostki, zadania, jakie wykonuje na rzecz społeczeństwa, zgłaszane potrzeby społeczności lokalnych, wielkość jednostki, otoczenie, w którym funkcjonuje (w tym czynniki zewnętrzne oddziałujące na daną jednostkę). Konieczna jest także znajomość wizji, misji i strategii. Inne istotne czynniki to stopień złożoności działań, struktura organizacyjna (umiejscowienie w niej budżetowania zadaniowego i kontroli zarządczej), instrukcje i wytyczne wewnętrzne. Brak wiedzy na temat tych zagadnień może zniekształcić ocenę dokonaną przez audyt i negatywnie wpłynąć na funkcjonowanie jednostki w przyszłości. Audytor powinien także dokonać osobistych obserwacji oraz porozmawiać z kluczowymi pracownikami, co pozwala na zidentyfikowanie obszarów problemowych (Moeller, 2011; Kiziukiewicz, Sawicki, 2013).

Zmodyfikowanie koncepcji budżetowania zadaniowego i kontroli zarządczej zgodnie z zaleceniami audytu zwiększa szanse na powodzenie i niejako daje pewność, że (por. Kiziukiewicz, Sawicki, 2013; Skoczylas-Tworek, 2013):

- wszystkie założone cele zostały określone jasno i będą osiągnięte (skuteczność) w odpowiedni sposób (efektywność),

- rzeczywiście realizowane zadania będą przyczyniały się do osiągania celów,

- procedury monitorowania opracowane są prawidłowo, a skonstruowane mierniki będą właściwie odzwierciedlać stopień osiągnięcia celów i sposób realizacji zadań,

- jednostka ma narzędzia pomiaru efektywności i skuteczności,

- zidentyfikowane jest ryzyko związane z osiąganiem celów,

- ryzyko zostanie ograniczone do dopuszczalnego poziomu,

- podejmowane działania będą zgodne z obowiązującymi przepisami.

Po wstępnym badaniu przeprowadzane mogą być testy sprawdzające, które za cel przyjmują ustalenie, czy funkcjonowanie kontroli zarządczej i budżetowania zadaniowego jest zgodne z przepisami obowiązującymi w jednostce (Kiziukiewicz, 2014). Po dokonaniu oceny, gdy audytor uzna badane rozwiązania za prawidłowe, zadaniem jego jest ustalenie, czy zostały w pełni zaimplementowane. Gdy okaże się, że nie są one dobrze zaprojektowane i wdrożone, czyli nie pełnią swej ideowej roli, niezwłocznie poinformowany powinien być o tym kierownik jednostki.

Po wdrożeniu budżetowania zadaniowego i kontroli zarządczej, uwzględniając zalecenia audytu, w dalszym ciągu występuje ryzyko dotyczące potencjalnych nieprawidłowości lub nieosiągnięcia założonych korzyści. Ważny dlatego jest bieżący monitoring obu koncepcji, który dokonywany jest przez kierownika jednostki, jak również okresowy, należący do 
kompetencji audytorów. Ma on za zadanie wskazać, dlaczego przykładowo nie został zrealizowany plan, a mierniki przyjmują niewłaściwe wartości. W praktyce oznacza to sprawdzenie, czy wdrożone systemy zgodne są z opracowaną koncepcją, oraz czy funkcjonują skutecznie i efektywnie. Rozwiązań zidentyfikowanych problemów dostarczają m.in. pracownicy, o czym audytorzy informowani są w trakcie wywiadów.

Audyt dokonując oceny mechanizmów funkcjonowania budżetowania zadaniowego i kontroli zarządczej, docelowo wpływa na zmiany w sposobie wykorzystywania tych instrumentów, a w rezultacie zarządzania całą jednostką. Koncentracja audytu następuje przede wszystkim na mankamentach systemów, a nie na konkretnych, indywidualnych przypadkach popełniania błędów (Kiziukiewicz, 2014), a wykazane w wynikach audytu niedoskonałości powinny być eliminowane. Informacje o zidentyfikowanych problemach należy szybko komunikować pracownikom, którzy są odpowiedzialni za wykonywane zadania oraz ich przełożonym, a o poważnych nieprawidłowościach powinno zostać poinformowane najwyższe kierownictwo (Ochmańska, Jarząbek, 2012). Audyt stanowi więc zabezpieczenie przed nieefektywnym i nieskutecznym zarządzaniem jednostką.

Międzynarodowe standardy również wskazują na istotną rolę audytu w systemie kontroli. W jednym z nich wskazane jest, że „audyt wewnętrzny musi wspierać organizację w utrzymaniu skutecznych mechanizmów kontrolnych poprzez ocenę ich skuteczności i wydajności oraz promowanie ciągłego usprawniania" (Komunikat z dnia 12 grudnia 2016 r.).

Podsumowując, audyt powinien obejmować badanie efektywności, wydajności, skuteczności oraz adekwatności systemów budżetowania zadaniowego i kontroli zarządczej, które funkcjonują w jednostkach publicznych. Ocena powinna następować pod względem legalności, efektywności i gospodarności, celowości, rzetelności, wiarygodności, przejrzystości oraz jawności (Filipiak, 2011).

\section{Uwagi końcowe}

Efektywność funkcjonowania JST uzależniona jest od skuteczności kontroli zarządczej, budżetu zadaniowego oraz audytu wewnętrznego. Prowadzone zadania audytowe przyczyniają się istotnie do podniesienia jakości zarządzania, a ich znaczenie zostało wzmocnione ustawą o finansach publicznych, która sprecyzowała definicję audytu oraz wskazała na audyt wewnętrzny jako podstawowe narzędzie obiektywnej oceny kontroli zarządczej dla prawidłowego funkcjonowania jednostek publicznych. Staje się więc jednym z niezastąpionych narzędzi oceny zarządzania ryzykiem oraz określenia stopnia realizacji zaplanowanych zadań i celów przez kadrę zarządzającą. Stanowi także pewnego rodzaju wyznacznik dla wzrostu efektywności gospodarowania publicznymi zasobami finansowymi.

Informacje uzyskane $\mathrm{w}$ trakcie badania audytowego powinny posłużyć do zaproponowania usprawnień zmierzających do poprawy gospodarowania środkami publicznymi. Należałoby zatem oczekiwać, że system kontroli zarządczej i działania audytowe będą 
systematycznie i planowo wdrażane we wszystkich jednostkach sektora finansów publicznych, służąc usprawnieniu ich działalności i korygowaniu istniejących nieprawidłowości (Żółtkowski, 2015).

\section{Literatura}

Czerwiński, K. (2003). Książka procedur audytu wewnętrznego. Materiały niepublikowane. Warszawa: CISA.

Definicja audytu wewnętrznego, Kodeks etyki oraz Międzynarodowe standardy praktyki zawodowej audytu wewnętrznego (2016). IIA. Pobrane z: www.mf.gov.pl (29.05.2017).

Dylewski, M., Filipiak, B., Gorzałczyńska-Koczkodaj, M. (red.) (2010). Metody ilościowe w działalności jednostek podsektora samorzadowego. Warszawa: Difin.

Filipiak, B. (2011). Kontrola zarządcza w jednostkach samorządu terytorialnego - wybrane aspekty. W: T. Lubińska (red.), Kierunki modernizacji zarządzania w jednostkach samorzadu terytorialnego (s. 347-363). Warszawa: Difin.

Kiziukiewicz, T. (2014). Audyt wewnętrzny jako narzędzie oceny kontroli zarządczej. W: K. Winiarska (red.), Kontrola zarzadcza oraz audyt wewnętrzny $w$ teorii i praktyce (s. 13-26). Szczecin: Wydawnictwo Uniwersytetu Szczecińskiego.

Kiziukiewicz, T., Sawicki, K. (2013). System kontroli zarządczej jako szczególny obszar audytu. W: T. Kiziukiewicz (red.), Audyt wewnętrzny w strukturze kontroli zarządczej (s. 327-352). Warszawa: Difin.

Komunikat Ministra Rozwoju i Finansów z dnia 12 grudnia 2016 r. w sprawie standardów audytu wewnętrznego dla jednostek sektora finansów publicznych (Dz. Urz. Min. Rozw. i Fin. poz. 28).

Komunikat nr 23 Ministra Finansów z dnia 16 grudnia 2009 r. w sprawie standardów kontroli zarządczej dla sektora finansów publicznych (Dz. Urz. Min. Fin. nr 15, poz. 84).

Lubińska, T. (2009). Budżetowanie zadaniowe w kontekście zasad podatkowych i zasad budżetowych. W: S. Wieteska, M. Wypych (red.), W poszukiwaniu efektywności finansów publicznych (s. 86-94). Łódź: Uniwersytet Łódzki.

Lubińska, T., Strąk, T., Lozano-Platonoff, A., Będzieszak, M., Godek, M. (2007). Budżet zadaniowy w Polsce istota, struktura, metodyka. W: T. Lubińska (red.), Budżet zadaniowy w Polsce. Reorientacja z wydatkowania na zarządzanie pieniędzmi publicznymi (s. 15-72). Warszawa: Difin.

Łagodzki, P. (2011). Audyt wewnętrzny - wybrane zagadnienia. Zeszyty Naukowe Uniwersytetu Szczecińskiego, 625. Finanse. Rynki Finansowe, Ubezpieczenia, 32.

Moeller, R. (2011). Nowoczesny audyt wewnętrzny. Warszawa: Wolters Kluwer.

Ochmańska, L., Jarząbek, T. (2012). Organizacja kontroli zarządczej w jednostkach sektora finansów publicznych. W: K. Winiarska (red.), Kontrola zarządcza w jednostkach sektora finansów publicznych (s. 102-133). Warszawa: Wolters Kluwer.

Opracowanie dotyczace wyjazdu studyjnego przedstawicieli Ministerstwa Finansów do Królestwa Norwegii, realizowanego jako szkolenie, Wzorce budżetów zadaniowych, rozwiązania zagraniczne na przekładzie Norwegii (2008). Warszawa: Ministerstwo Finansów.

Skoczylas-Tworek, A. (2013). Budżet zadaniowy, jako wyzwanie dla audytorów, wewnętrznych jednostek sektora finansów publicznych. Zeszyty Naukowe Uniwersytetu Szczecińskiego, 766. Finanse, Rynki Finansowe, Ubezpieczenia, 62.

Skrzypek, E. (2011). Nowe zarządzanie publiczne. W: A. Siedlecka (red.), Budżet zadaniowy jako nowoczesne narzędzie zarządzania gospodarka narodowa. Biała Podlaska: PSW im. Papieża Jana Pawła II w Białej Podlaskiej.

Ustawa z 27 sierpnia 2009 r. o finansach publicznych (t.j. Dz.U. 2016, poz. 1870 z późn. zm.).

Welcome to the world in PIFC Public Internal Financial Control (2006). European Commission. Pobrane z: www. sigmaweb.org/publicationsdocuments (22.05.2017).

Zawadzka-Pąk, U.K. (2013). Ogólna kontrola efektywności i skuteczności budżetu w układzie zadaniowym. W: E. Ruśkowski, J.M. Salachna (red.), Finanse publiczne. Komentarz praktyczny. Gdańsk: ODDK.

Żółtkowski, R. (2015). Kontrola zarządcza i audyt wewnętrzny jako instrumenty zmniejszające naruszenie dyscypliny finansów publicznych w zamówieniach publicznych. W: E.I. Szczepankiewicz, A. Kamela-Sowińska, R. Żółtowski, J. Klak, A. Szyba, K. Młynarczyk, M. Witkowska, A. Luma, Kontrola zarządcza i audyt wewnętrzny w jednostkach samorządu terytorialnego. Warszawa: Wolters Kluwer. 


\section{INTERNAL AUDIT FUNCTION IN TASK-BASED BUDGETING AND MANAGEMENT CONTROL IN A LOCAL GOVERNMENT UNIT}

Abstract: Purpose - Presenting the role of internal audit in performance budgeting and management control. Design/methodology/approach - Analysis of the literature, legal acts, source materials, observation and individual interviews with employees of the audited entities (head of budget department and 4 persons employed in those departments).

Findings - The role of audit activities in the functioning of performance budgeting and management control has been presented and the interdependencies between them are described.

Originality/value - Achieving goals and carrying out tasks by local government units requires the use of different instruments in the decision-making process. Therefore, management should be aware that proper performance budgeting, management control and internal audit should be properly linked to maximize the benefits.

Keywords: internal audit, management control, performance budgeting

\section{Cytowanie}

Szołno, O. (2017). Audyt wewnętrzny w doskonaleniu budżetowania zadaniowego oraz kontroli zarządczej w jednostce samorządu terytorialnego. Finanse, Rynki Finansowe, Ubezpieczenia, 3 (87/1), s. 197-204. DOI: 10.18276/ frfu.2017.87/1-18. 